\title{
Mutual recognition in criminal matters in Cyprus
}

\author{
by Theodora Christou, Eleni Kouzoupi, and Helen Xanthaki
}

\section{INTRODUCTION: THE REPUBLIC'S LEGAL SYSTEM}

I n 1960 Cyprus was proclaimed an independent and sovereign republic. After independence the English legal system and principles of equity and the common law were maintained, while preserving civil law tradition in family and administrative law. These are accompanied by the Constitution of the Republic of Cyprus and laws subsequently enacted by the House of Representatives.

The hierarchy of these laws is one area where difficulties have been encountered vis a vis national and European law (see R Ayres, "European integration: the case of Cyprus", Cyprus Review, 1996, pp 39-62). Following what has been coined "the arrest warrant case", and within the framework of cooperative constitutionalism, EU law is now confirmed as supreme and sitting above the constitution.

The Attorney-General is a party to all domestic legal proceedings pursued against the republic, or by it, and defends or institutes the proceedings in court, as the case may be, through a counsel of the Law Office. Moreover all prosecutions are instituted and conducted by the AttorneyGeneral and counsel of the Law Office acting under his instructions (see A Neokleous, Introduction to Cyprus law, New York, Yorkhill Law Publishing, 2000, p 27).

With respect to mutual cooperation in criminal matters, at first instance requests are dealt with by the District Courts of which there are six (Nicosia, Famagusta, Limassol, Larnaca, Paphos and Kyrenia). These decisions can in certain circumstances be appealed to the Supreme Court from which there is no further appeal.

Judges in Cyprus are appointed after working as a qualified lawyer. There is no judicial training school in Cyprus, with the responsibility falling on the Supreme Court.

\section{MUTUAL RECOGNITION IN CRIMINAL MATTERS: THE PRESENT}

\section{Mutual recognition in general}

In general, the principle of mutual recognition, as a successor to the ineffective mechanisms of mutual legal assistance, is respected and well established in Cyprus law (see H Xanthaki, "Judicial Cooperation in Criminal
Matters: the Puzzle Revealed" 8 [2006] 2 Special Issue on EU criminal law, European Journal of Law Reform, pp 17598). The republic fully adopted all relevant Framework Decisions within the set time limits, and does not require reciprocity between Member States as a prerequisite for mutual recognition implementing measures. Also, mutual recognition of final judgments is not viewed differently from mutual recognition of pre-trial decisions.

Moreover, the republic chose to proceed with the express transposition of the general provision on fundamental rights which refers to Article 6 of the Treaty on European Union (TEU) in the national implementing measures on mutual recognition as a means of clear and categorical reassurance of the EU and other Member States that Article 6 TEU applies. This was undertaken despite the doubtful legal value of the provision in practice: after all in Cypriot law human rights issues apply even where there is no express provision in the relevant instrument. Furthermore, Cyprus made a big compromise in agreeing to the inclusion to some instruments (such as the Framework Decision on the transfer of prisoners) of the territoriality clause enabling a member states to refuse to recognise and execute a decision issued for an offence wholly or partly committed on its territory. Cyprus disagreed with that provision for three main reasons: its antithesis to the Cypriot Constitution, to the essence of the principle of mutual recognition and mutual trust, and to the scope of the instrument on the transfer of prisoners which was after all the rehabilitation of the convicted.

In addition to the above, Cyprus has had to set aside procedural differences in the recognition and execution of decisions between its common law system and the continental system of many EU Member States: so far few difficulties in recognising and execution of decisions have been encountered. An example demonstrating this point can be drawn from judgments in absentia: although these are provided for in Cypriot law in exceptional and rare circumstances, the republic did not view this as an obstacle for Cyprus's acceptance of the Framework Decision (FD) on judgments in absentia. Further evidence of this positive approach can be found in the religious transposition of mutual recognition instruments into Cypriot law. Thus, the provisions on dual criminality are transposed exactly in the 
way they are worded in the Framework Decision on the European arrest warrant (EAW), where it is practically retained. Similarly, the provisions on the territoriality clause are transposed in exactly the manner that they are worded in the Framework Decision on the EAW.

Nevertheless, mutual recognition in Cyprus should not be viewed as an absolute right. Firstly, the reference to the fundamental rights in the mutual recognition instruments (Art 1 (3) of FD 13 June 2002, Art 1 of FD 22 July 2003, Art 3 of FD of 24 February 2005, p 8) implies that a control should be exercised by the executing authority (grounds for refusal) on the procedural safeguards and the respect of the rights of defence in the issuing Member States, especially if the issue is raised by the defence. This concern is shared by others: (see S Alegre and M Leaf, "Mutual recognition in European judicial cooperation: a step too far too soon? Case study - the European arrest warrant", European Law Journal, 2004, pp 200-17).

Secondly, and perhaps more importantly, the Cypriot Constitution sets commonly underestimated limits to the transposition and implementation of the principle of mutual recognition. Although in practice the republic ensures that the relevant instruments are adopted fully, even in contradiction of the constitution which has in the past been amendedto allow for the surrender of own nationals under the EAW, limits have been placed with reference to the date of commission of the offence for which a person is wanted. The need for these limits, which are not unique in the EU, refer to Parliament's view that otherwise there would be retrospective application of the implementing law on the EAW, which would be contrary to the constitution. In fact, the fifth amendment of the Cypriot constitution provides that no provision of the constitution shall be considered as annulling laws, acts or measures taken by the republic in compliance with its obligations as a Member State of the EU.

Moreover, based again on constitutional grounds, double criminality is considered an additional ground for refusal (see V Mitsilegas, "The constitutional implications of mutual recognition in criminal matters matters in the EU," Common Market Law Review, 2006, pp 1277-1311). Thus, the republic requested the inclusion of paras (3) and (4) in Article 10 of the Framework Decision on alternative sanctions. Under Article 10, for offences not covered by paragraph 1 the executing state may make the recognition of the judgment, the probation decision, and the supervision of probation measures and of alternative sanctions subject to the condition that the judgment relates to acts which also constitute an offence under the law of the executing state, whatever its constituent elements or however it is described.

Furthermore, the republic took additional measures in its implementation of the EAW in order to ensure that transposition would not create a vacuum: the implementing law on the EAW provides that it applies only between Cyprus and the Member States of the EU which also have fully implemented the Framework Decision on the EAW; as a result, countries that have properly, in accordance with the Framework Decision declared that they would execute an EAW only in relation to acts committed after the set date, the European Convention on Extradition can still apply in relation to those acts. Also, the implementing law provides that extradition requests received before the operation of this law are handled in accordance with the previous regime (the European Convention on Extradition). In addition to these points, it is noteworthy that in the implementing legislation of the Framework Decision on the EAW surrender may be refused if the persons are wanted for their fight for freedom; however, the provision has been criticised and the republic is in the process of bringing a Bill before the House of Representatives for its deletion.

But, do nationals and residents receive a particular status in the relevant national implementing measures of EU instruments on mutual recognition? In principle, all EU citizens enjoy the same status. However, in the case of the EAW, nationals and residents receive the status provided in the Framework Decision on EAW except for the fact that they can only be surrendered for actions committed after Cyrus acceded to the EU.

\section{The European Arrest Warrant}

The EAW is at the centre of the developing EU criminal justice and embodies many of the principles, including mutual recognition. Thus, the implementation of the EAW is a good example of how Cyprus has embraced the EU Criminal Justice mechanisms. The EAW Framework Decision (2002/584/JHA: Council Framework Decision of 13 June 2002 on the European arrest warrant and the surrender procedures between Member States) was implemented by Law No 133(I) of 2004 on the European Arrest Warrant and the Surrender Procedures of Required Persons. On the whole its transposition is regarded as a success, as the Commission's report on the implementation of the FD since 2005 confirms (11 July 2007, COM92007) final).

There are few departures from the Framework Decision, and where they exist they tend to extend the scope or purpose of the Decision. For example, in relation to the mandatory reasons for non-execution of an EAW in the interests of constitutional compatibility and protection of human rights, Article 13 of the Law goes beyond what is required under Article 3 of the Decision. It states:

(d) if the European arrest warrant has been issued for the purpose of prosecuting or punishing a person on the grounds of his or her sex, race, religion, ethnic origin, nationality, language, political opinions, sexual orientation or activity for freedom,

(e) if the person who is the subject of the European arrest warrant, for the execution of custodial sentence or 
detention order, is a national and the Republic of Cyprus undertakes the obligation to execute the sentence or detention order according to its criminal laws,

(f) if the person who is the subject of the European arrest warrant for his prosecution is a national, unless it is ensured that after being heard, he or she shall be transferred to the Republic of Cyprus, in order to serve a custodial sentence or a detention order which shall be passed against him/her in the issuing State of the warrant.

The report of the Commission on the implementation of the EAW (6815/05 ADD 1 COPEN 42) notes that the reference to "action in favour of freedom" in Article 13(d) of the Law was wider, creating a risk that a refusal will go beyond the Decision. As a result of this a proposal was put before the Parliament to delete this reference.

The central authority for issuing and executing EAWs is the Ministry of Justice and Public Order. Within this framework, the key actors include the police force, the Law Office of the Republic of Cyprus and the District Judges. In addition to the human rights guarantees inserted above, there are good pre-trial procedural guarantees in place. For example those arrested have the right to both a legal counsel and interpretation, importantly as of right and practice.

It is worth pondering the practical steps taken in the issuance and the execution of an EAW. As a first step the police must present the case to the Attorney-General who will give an opinion on whether an EAW should be issued. The police will then draft the proposed warrant and present it to the Attorney-General for a decision. The decision will be based on the proportionality principle, the seriousness of the offence, the situation of the victim, and the date of the offence. The Attorney-General will also ensure that the EAW is drafted correctly.

The EAW, domestic arrest warrant and any evidence is then presented before a District Judge, which he will sign if satisfied they comply with the law. Once issued, the EAW is transmitted by the police to Interpol Nicosia and the central authority who will then transmit to the receiving authority. This procedure acts as a double check ensuring that procedural mistakes/omissions in issued EAWs are avoided, as is the issue of triviality existing in many of the other Member States. Such a process will appear cumbersome to many of the larger Member States who are currently struggling to execute EAWs within the set time limits.

However, when it is considered that the purpose of the Decision is to promote cross border interaction between authorities and in particular peer interaction between the judiciary, in practice this is not fulfilled, despite the clear law set out in the Decision as well as Article 8 of the Law, which states that a District Judge may transmit the incoming EAW directly to the executing judicial authority. The judiciary themselves also appear reluctant to communicate with other judges for clarification. This reluctance is largely based on the perceived role of a judge in the common law setting. A possible resolution to this could be the creation of a network of judges focused on the EAW and mutual recognition in criminal matters.

The EAW, whilst transposed under law distinct to the domestic arrest warrant, it is still very much connected. It is understandable that for outgoing requests a domestic arrest warrant needs to be issued as a first step and only after the evidence indicates that the person is found abroad is an EAW issued. However such a requirement for the execution of an EAW goes against the spirit of the Decision; for incoming requests a domestic arrest warrant needs to be issued before a person can be arrested under an EAW. Whilst this means that the procedures and procedural guarantees in place for domestic arrest warrants are of equal applicability for EAWs, it could also lead to problems in the future.

The existence of a centralised database, the STOP-LIST, helps ensure the avoidance of duplicitous warrants. Looking to the future it will be interesting to see how this database is coordinated with the Sirene Bureau set up as part of the Schengen Information System (SIS), as well as whether access will be granted to Customs and MOKAS.

The problems encountered to date by Cyprus are best illustrated through consideration of the case law on the issues. The first case is Scattergood $v$ Attorney-General, 12/2005, 21 January 2005, in which Scattergood, who had pleaded guilty in a UK court to two charges of conspiring to import illicit drugs and was released on a recognisance. His return from Cyprus was being sought by the UK. His lawyer argued that his client had been arrested following the issuing of an arrest warrant in violation of Article 11 of the constitution, since it was based on provisions of the Criminal Procedure Law and not on provisions of the Law for the European Arrest Warrant -Law No 133 (1)/2004. The Supreme Court rejected that argument, noting that the issuing of an arrest warrant by a court in Cyprus is not a sine qua non condition for jurisdiction by the Courts in Cyprus. The jurisdiction of a court in Cyprus emanates from the EAW itself because, by virtue of Article 3 of the Law No 133(1)/2004, it is an order of a judicial authority of the EU Member State that is issued in the context of a criminal procedure for the purpose of having the requested person arrested and handed over to the issuing state.

Scattergood also submitted that his life would be in danger if returned to the UK because he had been willing to appear as a prosecution witness against his co-accused. It was asserted that this was no longer an issue since he was not going to be a witness. The Supreme Court first considered the obligation of a state to protect a requested person not only from acts of the state but also from the acts of private persons, stating that where the danger posed is a violation of Article 3 of the ECHR, given the absolute 
character of the provision, serious consideration must be given to the allegations.

After examining the facts of the present case, the court concluded that the appellant would not be in any greater danger in the United Kingdom than he would be in Cyprus. The appeal was rejected and the individual surrendered.

In the case of Ovakimyan v Attormey-General, 266/2005, 19 September 2005, the District Court of Limassol ordered the implementation of the EAW issued by the Dutch authorities against the appellant. The appeal to the Supreme Court was based on two issues. Firstly that competence for issuing EAW cannot be granted to Public Prosecutors under the Framework Decision. On this issue the Supreme Court held that under Dutch law the Public Prosecutor, although operating under the responsibility of the Ministry of Justice, constitutes part of the judicial authority. Further, the competent authority for the issuing of an EAW does not need to be a judge but can also be a Public Prosecutor as allowed under Dutch law and that it was up to each Member State to decide how to give effect to a Framework Decision which states that is to be issued by a "judicial authority."

Secondly, there was an assertion that the EAW was not properly issued. Whilst an original was not sent, the English translation was also signed by a second individual and not the authorising public prosecutor. The Supreme Court rejected these arguments finding that the whole administrative and judicial procedure operated reasonably within the spirit of Article 10 (4) (5) of the Framework Decision and of Articles 4 and 8 (4) (5) of the Law. The appeal was rejected.

The next case is that of Attorney-General $v$ Konstantinou, 294/2005, 7 November 2005, where the surrender of a dual British and Cypriot national was requested by the UK from Cyprus under an EAW. Here the Supreme Court considered within the context of the prohibition on extraditing its own nationals, firstly whether the EAW Law was implemented contrary to the constitution, and secondly the relationship between the constitution and EU law.

The unanimous decision held that Article 11 of the constitution included an exhaustive list of reasons as to when a person can be arrested, which did not include for the purposes of an EAW and quoting its previous judgment in Georgiou $v$ Director of Central Prisons (1991) which confirmed the constitutional prohibition of extraditing its own nationals. Further it ruled that the correct legal procedure should be followed to ensure that the EAW is implemented into Cypriot law:

This case led to a Constitutional amendment with Article 11 now reading:

"Arrest or withholding of a person with intent to obstructing the entrance without permit into the territory of the Republic or arrest or withholding of an alien against whom actions were taken with intent to deport or extradite or arrest or withholding a citizen of the Republic in order to extradite or surrender him, having in mind the reservations of the following provisions:

$[\ldots]$

The arrest or withholding of a citizen of the Republic with the intention of surrendering him based on a European Arrest Warrant is possible only with regard to facts that supervened or actions committed after the date of accession of the Republic into the European Union..."

The most recent case to be heard by the Supreme Court relating to the EAW is Andersson v Attorney General, 349/08. This case illustrates the strong commitment of the Cypriot authorities to fulfil their EU obligations, whilst at the same time paying due regard to the procedural safeguards.

On 1 September 2008 the Swedish authorities transmitted to the Cypriot Police an EAW for the appellant for her arrest and surrender in relation to her alleged participation in criminal offences committed in Sweden. On 8 October 2008 the appellant was arrested and presented before the court within 24 hours. The appellant did not consent to her surrender and a date for a hearing was set. On 31 October 2008 the District Court of Larnaca ordered the implementation of the EAW and the surrender of the appellant to the Swedish authorities. At the same time it ordered that she remain in custody until the date of her surrender.

The decision was appealed to the Supreme Court on three grounds. The first was that the Swedish Public Prosecutor of the Economic Crimes Bureau was not the responsible authority for the issuing EAWs. This contention was examined and rejected by the first instance court. As noted from the translation of the EAW it is clear that no conviction was issued against the appellant and the surrender to the Swedish authorities was not to serve a sentence, but as a suspect for the commitment of alleged criminal offences for her prosecution. It was also clear from the letter of the Swedish Central Authority to the Cypriot Central Authority that every Public Prosecutor in Sweden, including the Public Prosecutors in the Office of Financial Crime, is a competent judicial authority for issuing the EAW. For the above reasons the Supreme Court adopted the first instance judgment.

Under the second ground it was claimed that the first instance court relied mistakenly on the evidence which was deposited before it at the beginning of the procedure. However, since the issue was not raised at first instance it could not constitute a ground of appeal. In addition it was noted by the court that at the beginning of the first instance procedure, a report of all the relevant documents relied upon was presented to the appellant's lawyer who did not object nor raise any issue of unconstitutionality.

The third ground for appeal was that the first instance court mistakenly rejected the medical evidence. On this 
issue the court noted that it was connected to the EAW procedure, but with the suspension of the execution of the judgment. This falls under Article 29(3) of Law 133( $\pi$ ) of 2004 , according to which the decision to implement an EAW can be suspended for serious humanitarian reasons or if it is believed that the implementation might endanger the life or the health of the requested person. Accordingly a written submission should be made to the Central Authority, which will inform the judicial authorities so a new date for surrender can be fixed. Within the above framework the court held that this ground of the appeal was not related to the substance of the validity of the first instance judgment. Under the circumstances the appeal was dismissed.

The constitutional amendment which now permits the surrender of Cypriot nationals under an EAW is still problematic with regards to the limitation that they will only be surrendered for crimes committed after Cyprus' accession on 1 May 2004. As stated in the evaluation report, this is a clear violation of Article 32 of the Decision which provides:

\section{Extradition requests received before 1 January 2004 will continue to be governed by existing instruments relating to extradition. Requests received after that date will be governed by the rules adopted by Member States pursuant to this Framework Decision. However, any Member State may, at the time of the adoption of this Framework Decision by the Council, make a statement indicating that as executing Member State it will continue to deal with requests relating to acts committed before a date which it specifies in accordance with the extradition system applicable before 1 January 2004. The date in question may not be later than 7 August 2002.}

This limitation is likely to cause frustration amongst requesting states and in particular once the SIS is in place with its several thousand requests, many dating before May 2004. Cyprus's view is that to have otherwise would violate the non-retroactivity principle. This is however not accepted in the evaluation report as a valid ground since they regard the retroactivity rule as applying only to substantive criminal law and not procedural law. Further, this clause in is contradiction with the constitution itself which clearly states that EU law is supreme. If not amended before hand, this constitutional conflict will need to be resolved by the judges.

On the basis of the information submitted to the Working Party on Cooperation in Criminal Matters (Experts on the European Arrest Warrant - most recent 11 June 2008, 10330/08 COPEN 116 EJN 44 EUROJUST 58), it appears that there are no major problems with the application of the EAW in Cyprus. The domestic procedures are in place to facilitate the smooth and efficient running of both incoming and out going requests, with the key actors working well together to facilitate the execution of requests. From all accounts the surrender procedure occurs within the time limit set by
Article 17 (4) and Article 23 (2) of the Framework Decision. This is no doubt facilitated by the relatively small population and small number of EAWs it has to deal with.

On the other hand the very procedural approach adopted by the authorities is detrimental to at the spirit of mutual recognition. In particular this can be seen by the minimalist involvement of the judiciary in the whole process. In addition to efficient procedures, mutual trust amongst the judiciary is key to the strengthening of mutual recognition and the successful evolution cross-border cooperation.

\section{MUTUAL RECOGNITION IN CRIMINAL MATTERS IN PRACTICE}

Cyprus views the EU as a route guaranteeing stability, democracy and peace on the island (see for example A Theophanous, "Prospects for solving the Cyprus problem and the role of the European Union,' Publius, 2000, pp 217-46). As a result, Cypriots are aware of EU matters. Policy makers have a clear picture about the principle of mutual recognition. It is understood as a principle designed to strengthen cooperation between member states. More specifically, it is understood that once a judgment is delivered in one Member State it is not open to challenge in another Member State but it is recognised and executed. In that sense mutual recognition of decisions contributes to legal certainty in the European Union. It is also understood that implementation of the principle of mutual recognition of decisions in criminal matters presupposes that member states have trust in each others' criminal justice systems.

Policy makers are familiar with the principle of mutual recognition as introduced in the Framework Decision on the European arrest warrant, Framework Decision on the transfer of prisoners, Framework Decision on alternative sanctions and Framework Decision on judgments in absentia. Practitioners are not involved in negotiations phase, which is conducted primarily by the Law Office of the Republic of Cyprus and the Ministry of Justice.

Practitioners who deal with mutual recognition cases before the national courts have a clear picture of the principle of mutual recognition. Dual criminality and territoriality seem to apply as provided for in the instruments of mutual recognition. No problems have surfaced relating to co-operation between Member States, as there is no jurisprudence related to dual criminality and territoriality.

However, the non-participation of practitioners in negotiations or in the drafting of national implementing legislation leads to a lack of awareness of debate in the field of judicial co-operation in criminal matters and more specifically the mutual recognition instruments. The problem is accentuated by the lack of training in the field for practitioners: so far only two seminars have been organised by TAIEX in Cyprus. Moreover, there is no feedback mechanism on the results of mutual recognition 
in practice post facto, and no forum for discussion of experiences, problems encountered and the resolution of those problems. There is no record of individual cases decided upon on the basis of mutual recognition, and no relevant statistics are available.

\section{MUTUAL RECOGNITION IN CRIMINAL MATTERS: THE FUTURE}

\section{General}

The future of mutual recognition is not easy to foresee. By definition, the principle seems to be plagued by the fragmentation of EU criminal law, the fluidity of criminal law bodies and agencies, the overlap of such agencies promoting cooperation in criminal issues, and the conflicting interests of Member States some of which support further integration whereas others reject the whole idea altogether. In fact, for some the problem is a reflection of the view that the inclusion of new members, some of which have only limited experience with pluralistic democracy makes some Community Member States query whether the Council continues to be the most appropriate forum for the development of instruments promoting international cooperation in criminal matters.

As regards practical measures (measures to support and facilitate mutual recognition) in the field of judicial cooperation, there is much more that can be done now to enhance standards. This can be done by promoting good practice and EU funding in areas such as recording police suspect interviews, letters of rights, and the use of technology (eg video conferencing in cross border cases for obtaining evidence or interpretation). Further, given the linguistic challenges all national criminal justice systems face in consequence of free movement, consideration could be given, for example, to an EU telephone number anyone caught up in criminal proceedings could ring if they needed immediate interpretation help.

Although approximation of laws (substantive or procedural) cannot be viewed as a necessary prerequisite for further cooperation based on mutual recognition, there is support in the strengthening of citizen's procedural rights. This can be achieved without harmonisation of national criminal procedures.

\section{The European Arrest Warrant}

A welcome development which can only enhance the understanding and practice of mutual recognition would be a declaration under Article 36 of the EU Treaty which would allow the Cypriot courts to submit preliminary rulings to the European Court of Justice regarding interpretation of third pillar instruments, including the EAW decision.

The requirement to obtain a domestic warrant in addition to the existing EAW is a step which can be safely and legally abolished on the basis of the EAW Decision and Law as well as the constitution which only requires a "judicial warrant." It will also be at odds with the requirement for immediate arrest under the SIS.

The evaluation report has greatest praise for the efficiency of the mechanism in place and for the professionalism of the authorities. Nevertheless, the very procedural obedience to the Decision without appreciation of the wider European framework together with the consideration of the EAW and not as part of the wider principle of mutual recognition, evidenced by the limited judicial role is not healthy. As previously stated, the mutual trust principle is a foundation of the EU criminal justice system and the promotion of judicial cooperation. In the interests of the future of mutual recognition, for which there is no question of Cyprus' positive sentiments, the Central Authority needs to take a step back and allow judges to step up to their role as envisaged in the Decision.

- The views presented in this article are personal and can only be attributed to the authors in their personal capacity. They do not reflect, express or bind the views of the Republic of Cyprus.

\author{
Theodora Christou \\ European Cross Border Justice Project Manager, the AIRE Centre \\ Eleni Kouzoupi \\ Counsel of the Republic, Law Office of the Republic of Cyprus \\ Dr Helen Xanthaki \\ Senior Lecturer, Academic Director, Sir William Dale Centre for Legislative \\ Studies, IALS, University of London
}

